Editor Office : LPPM Sekolah Tinggi Teknologi Pagar Alam, Jln. Masik Siagim No. 75
Simpang Mbacang, Pagar Alam, SUM-SEL, Indonesia
Phone : +62 852-7901-1390.
Email : ngabdimas@lppmsttpagaralam.ac.id | ejournal@lppmsttpagaralam.ac.id
Website : https://ejournal.lppmsttpagaralam.ac.id/index.php/ngabdimas

\title{
PELATIHAN PEMBUATAN PETA MENGGUNAKAN ARCVIEW 3.3 PADA SMK NEGERI 1 PAGARALAM
}

\author{
Massagus Taswin \\ Program Studi Teknik Sipil; Sekolah Tinggi Teknologi Pagaralam (STTP) \\ Jl. M. Siagim No. 75. Karang Dalo, Dempo Tengah, Kota Pagar Alam \\ Telp/Fax: (0730) 621916 \\ e-mail: massa_gusta@gmail.com
}

\begin{abstract}
Abstrak
ArcView merupakan salah satu perangkat lunak (software) desktop Sistem Informasi Geografis (SIG) dan pemetaan yang dikembangkan oleh ESRI. ArcView memiliki kemampuan-kemampuan untuk melakukan visualisasi, meng-explore, menjawab query (baik basisdata spasial maupun non-spasial), menganalisis data secara geografis, dan sebagainya. Dengan diadakannya pelatihan Arcview bagi Siswa SMKN 1, diharapkan dapat mengenalkan proses pembuatan peta dengan perangkat lunak. Pelatihan itu mulai dari instalasi Arcview 3.3, membuka contoh peta digital, melihat layer-layer yang ada didalam peta digital, melihat data yang ada, menambahkan data pada peta, menggabungkan data dipeta dengan yang ada diluar peta, membuat peta tematik, membuat tambahan layer dari peta yang ada, hingga membuat layout untuk di print. Keuntungan diadakan pelatihan dengan menggunakan program ini adalah program yang cukup ringan sehingga dapat digunakan oleh netbook yang mempunyai prosesor intel atom (dengan catatan kalau bisa ram di naikkan $2 \mathrm{~Gb}$ agar tidak terlalu berat dan tidak ada program yang $c r a s h$ ). Dengan ini dapat memudahkan bagi siswa SMKN 1 untuk mempelajari dan memahami penggunaan program Arcview, sehingga adanya pelatihan ini mendukung kegiatan mencerdaskan anak bangsa yang menjadi pengabdian bagi Program Studi Teknik Sipil, Sekolah Tinggi Teknologi Pagaralam kepada masyarakat
\end{abstract}

Kata kunci- ArcView, ESRI, Siswa, peta, netbook, Pagaralam.

\section{PENDAHULUAN}

Peta adalah gambaran sebagian atau seluruh muka bumi baik yang terletak di atas maupun di bawah permukaan dan disajikan pada bidang datar pada skala dan proyeksi tertentu (secara matematis). Karena dibatasi oleh skala dan proyeksi maka peta tidak akan pernah selengkap dan sedetail aslinya (bumi), karena itu diperlukan penyederhanaan dan pemilihan unsur yang akan ditampilkan pada peta. Pembuatan peta ini dilakukan dengan perangkat lunak program Arcview.

Perangkat lunak sistem informasi geografi saat ini telah banyak dijumpai dipasaran. Masingmasing perangkat lunak ini mempunyai kelebihan dan kekurangan dalam menunjang analisis informasi geografi. Salah satu yang sering digunakan saat ini adalah ArcView. ArcView yang merupakan salah satu perangkat lunak Sistem Infrmasi geografi yang di keluarkan oleh ESRI (Environmental Systems Research Intitute). ArcView dapat melakukan pertukaran data, operasioperasi matematik, menampilkan informasi spasial maupun atribut secara bersamaan, membuat peta tematik, menyediakan bahasa pemograman (script) serta melakukan fungsi-fungsi khusus lainnya dengan bantuan extensions seperti spasial analyst dan image analyst (ESRI).

ArcView dalam operasinya menggunakan, membaca dan mengolah data dalam format Shapefile, selain itu ArcView jaga dapat memanggil data-data dengan format BSQ, BIL, BIP, JPEG, TIFF, BMP, GeoTIFF atau data grid yang berasal dari ARC/INFO serta banyak lagi datadata lainnya. Setiap data spasial yang dipanggil akan tampak sebagai sebuah Theme dan gabungan dari theme-theme ini akan tampil dalam sebuah view. ArcView mengorganisasikan komponen- 
komponen programnya (view, theme, table, chart, layout dan script) dalam sebuah project. Project merupakan suatu unit organisasi tertinggi di dalam ArcView.

Salah satu kelebihan dari ArcView adalah kemampaunnya berhubungan dan berkerja dengan bantuan extensions. Extensions bekerja atau berperan sebagai perangkat lunak yang dapat dibuat sendiri, telah ada atau dimasukkan (diinstal) ke dalam perangkat lunak ArcView untuk memperluas kemampuan-kemampuan kerja dari ArcView itu sendiri. Adanya pelatihan Arcview pada Sekolah Menengah Atas dapat memberikan pengetahuan dan pengenalan bahwa mengenai bagaimana pembuatan peta dasar menggunakan aplikasi tersebut.

\section{METODE}

Teknik yang digunakan dalam penyampaian materi pendampingan adalah workshop, dengan menggunakan alat bantu berupa laptop, LCD.

\subsection{Metode}

Pelatihan Arcview diadakan selama 1 hari. Materi disampaikan dan praktikum langsung yang diajarkan kepada siswa SMKN 1 Pagar Alam, setiap siswa mengoperasikan komputer masing-masing.

\subsection{Langkah-Langkah}

Langkah-langkah dalam pelatihan:

1. Setiap Peserta menginstal aplikasi Arcview, dilengkapi dengan extension tools yang compatible dengan arcview.

2. Pengenalan awal mengenai aplikasi arcview.

3. Materi Pelatihan dalam bentuk modul yang telah disusun secara sistematis

4. Penjelasan langkah langkah dalam modul yang ditampilkan, sehingga dapat memudahkan peserta mengikuti langkah langkah pelaksanaan operasional,

5. Peserta diberi Material latihan berupa peta hasil digitasi yang ada seperti Peta Kabupaten,untuk memudahkan latihan.

\subsection{Materi Program Arcview}

Software ArcView adalah software yang salah satu kegunaannya untuk editing, digitasi, pembuatan layout peta citra satelit. Software ini berjalan dibawah sistem dekstopmapping dengan menyediakan suatu kerangka kerja guna pembuatan keputusan spasial, dan mempunyai kemampuan untuk menggambarkan, menyelidiki, dan mengevaluasi, melakukan query danmenganalisis data spasial. Pekerjaan mengubah simbol peta, menambah gambar citra atau grafik, membuat informasi peta. Software Acview ini dapat mengubah icon-icon atau terminology yang digunakan pada interface, mengotomatiskan operasi-operasi atau membuat interface tertentu untuk melakukan akses ke data dasar terentu. Disamping ini Software ArcView juga dapat melakukan komunikasi dengan produk Software lain dimana dapat menggantidata tanpa melakukan konversi dan keluar dari ArcView.

\section{Komponen-Komponen ArcView}

Software ArcView mengorganisasikansistem perangkat lunak yang sedemikian rupa sehingga dapat dikelompokkan ke dalam beberapa komponen-komponen penting sebagai berikut :

\section{Project}

Komponen ini merupakan kumpulan dokumen-dokumen yang saling berhubungan, bekerja sama pada suatu sesion. Dokumen-dokumen tersebut meliputi view, table, chart, layout, script,. Suatu project mengorganisasi dan menyimpan suatu dokumennya. Project melakukan pengaturan bagaimana dan dimana dokumen didisplay. Suatu project disimpan 
dalam suatu file yang disebut project file yang berformat ASCII dan mempunyai extension.apr.softwareini dapat menampilkan satu projwct windows dalam sau sesion.

\section{Theme}

Theme merupakan suatu bangunan dasar ArcView.Theme merupakan kumpulan dari beberapa layer ArcView yang membentuk suatu tematik tertentu. Sumber data yang dapat dipresentasikan sebagai Theme adalah shapefile, coverage dan citra raster.

View mengorganisasikan theme. Sebuah view merupakan representasi grafis informasi spasial dan dapat menampung beberapa theme atau layer informasi spasial (titik, garis, poligon, dan citra raster). Sebagai contoh, posisi-posisi kota (titik), sungai (garis), dan batas propinsi (polygon) dapat membentuk suatu theme dalam sebuah view.

\section{Table}

Sebuah table merupakan representasi data ArcView dalam bentuk sebuah tabel. Sebuah tabel akan berisi informasi deskriptif mengenai layer tertentu. Setiap record mendefinisikan seetiap kolom mendefinisikan karakteristik dari entry yang bersangkutan. Dari sisi pengguna, tanpa memperhatikan sumber-sumbernya, semua tabel adalah sama. ArcView mendefinisikan template standart untuk merujuk table yang diakses.

\section{Chart}

Chart merupakan representasi grafis dari resumer tabel data atau hasil dari suatu query terhadap suatu tabel data. Bentuk chart yang didukung oleh ArcView adalah line, bar, column, xt scatter, area dan pie.

\section{Layout}

Layout digunakan untuk menggabungkan semua dokumen (view, table, chart) kedalam suatu dokumen yang siap untuk ditampilkan.

\section{Script}

Script merupakan bahasa pemrograman sederhana yang digunakan untuk mengotomatiskan kerja ArcView. ArcView menyediakan bahasa sederhana ini dengan sebutan avenue. Dengan Avenue pengguna dapat memodifikasi tampilan ArcView, membuat program menyederhanakan tugas yang komplek dan berkomunikasi dengan aplikasi lain. Dengan kata lain ArcView dapat dicustomize sedemikian rupa sehingga dapat secara optimal memenuhi pengguna untuk tugas-tugas dan aplikasi tertentu.

\section{Tampilan Arcview}

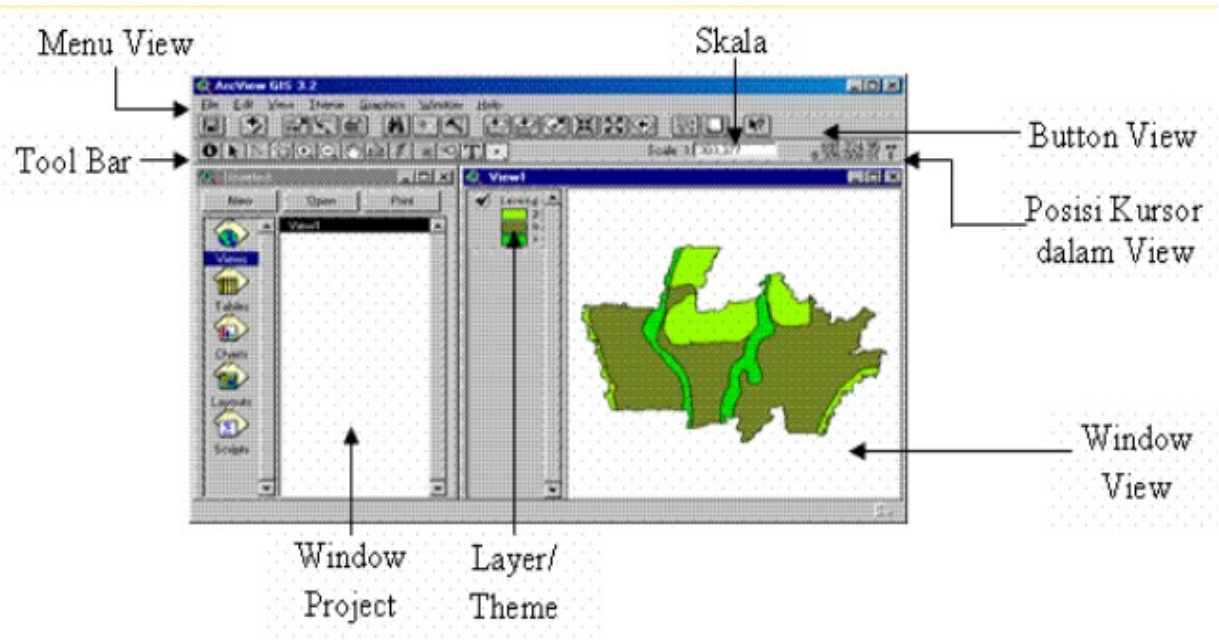

Gambar 1. Tampilan Arcview 


\subsection{Penyelesaian Masalah}

Pelatihan Pemetaan Arcview, adalah salah satu pemetaan dengan menggunakan salah satu perangkat GIS yang tersedia saat ini, seperti, Arcinfo, Mapinfo, Autocad, ArcGis, Arcview dan lain sebagainya. Penggunaan arcview sangat kurang digunakan pada dunia kerja saat ini, karena keterbatasan keterampilan mengenai ArcView.

\section{HASIL DAN PEMBAHASAN}

Maka berdasarkan pengabdian yang dilakukan sesuai dengan urutan pelaksanaan metode yang digunakan dalam pengabdian, maka:

\subsection{Hasil}

Kegiatan pelatihan aplikasi Arcview bagi SMK N 1 Kota Pagar Alam telah terlaksana dengan baik dengan diikuti oleh siswa/i SMK N 1, Kecamatan Pagar Alam Selatan Kota Pagar Alam dengan peserta 15 Orang.

\subsection{Pembahasan}

SIG mulai dikenal pada awal tahun 1980-an. Sejalan dengan berkembangnya perangkat computer, baik perangkat lunak maupun perangkat keras - SIG berkembang sangat pesat pada tahun 1990-an. Secara umum SIG atau Geographic Information System (GIS), merupakan suatu sistem (berbasiskan computer) yang digunakan untuk menyimpan, dan menganalisis objek-objek dan fenomena- fenomena dimana lokasi geografis merupakan karakteristik yang penting atau kritis untuk dianalisis.Dengan demikian, SIG merupakan sistem komputer yang memiliki empat kemampuan berikut dalam menangani data yang bereferensi geografis:

a. Masukan.

b. Keluaran.

c. Manajemen data(penyimpanan dan pemanggilan data).

d. Analisis dan manipulasi data.

Pemetaan secara komputerisasi dan analisa keruangan telah dikembangkan secara serempak di beberapa bidang/disiplin. Hal ini tidak akan mencapai hasil yang baik tanpa kerjasama antar masing bidang tersebut. Menurut Hans De Brouwer 1994, berbagai bidang yang terlibat dalam pengembangan SIG diantaranya yaitu:

- Pemetaan tanah dan pemetaan prasarana kota

- Pemetaan kartografi dan peta tematik

- Ukur tanah dan fotogrametri

- Penginderaan jauh dan analisa citra

- Ilmu computer

- Perencanaan wilayah (Planologi)

- Ilmu tanah

- Geografi

Berdasarkan sejarah perkembangannya, SIG dengan cepat menjadi peralatan utama dalam pengelolaan sumber daya alam. SIG banyak digunakan untuk membantu pengambilan keputusan dengan menunjukan bermacam-macam pilihan dalam perencanaan pembangunan dan konservasi.

ArcView merupakan salah satu perangkat lunak desktop SIG dan pemetaan yang dikembangkan oleh ESRI (Environmental Systems Research Institute, Inc). Dengan 
ArcView, anda dapat memiliki kemampuan-kemampuan untuk melakukan visualisasi, meng-explore, menjawab query (baik basis data spasial maupun non spasial), menganalisis data secara geografis, dan sebagainya.

ArcView dalam operasinya menggunakan, membaca dan mengolah data dalam format Shapefile, selain itu ArcView jaga dapat memanggil data-data dengan format $B S Q$, $B I L, B I P, J P E G, T I F F, B M P$, GeoTIFF atau data grid yang berasal dari ARC/INFO serta banyak lagi data-data lainnya. Setiap data spasial yang dipanggil akan tampak sebagai sebuah Theme dan gabungan dari theme-theme ini akan tampil dalam sebuah view. ArcView mengorganisasikan komponen-komponen programnya (view, theme, table, chart, layout dan script) dalam sebuah project. Project merupakan suatu unit organisasi tertinggi di dalam ArcView.

\section{KESIMPULAN}

ArcView merupakan salah satu perangkat lunak desktop SIG dan pemetaan yang dikembangkan oleh ESRI. Dengan ArcView, anda dapat memiliki kemampuankemampuan untuk melakukan visualisasi, meng-explore, menjawab query (baik basis data spasial maupun non spasial), menganalisis data secara geografis, dan sebagainya. ArcView mengorganisasikan projects beserta tool yang tersedia kedalam bentuk sistem windows, menu, button, dan icon. Keseluruhan pengembangan (integrated development environment) dan graphical user interface ArcView terdapat dalam windows aplikasi utama. Semua interaksi dengan pengguna dilakukan di dalam area ini. Setiap tipe dokumen ArcView memiliki graphical user interface yang berbeda.

\section{SARAN}

Pelatihan ini merupakan pengenalan pembuatan peta dengan menggunakan aplikasi arcview. Pelatihan ini hendaknya diadakan rutin sehingga pengetahuan siswa mengenai pemetaan bertambah.

\section{UCAPAN TERIMA KASIH}

Penulis mengucapkan terima kasih kepada LPPM STTP.

\section{DAFTAR PUSTAKA}

[1] Muslim, B. 2018. Pelatihan aplikasi editing video dengan filmora., Laporan Pengabdian Kepada Masyarakat, LPPM STT Pagaralam.

[2] Nugroho, Arif Rianto Budi, S.T, M.Si. Tutorial ArcView GIS.Yogyakarta: UPN

[3] Nursa'ban, Muhammad, M.Pd. .PanduanPraktikum Pemetaan Digital Menggunakan ArcView 3.3. Yogyakarta: UNY

[4] As-syakur, Abd Rahman___. Modul Pengenalan ArcView Untuk Dasar Analisis Sistem Informasi Geografis (GIS). Denpasar

[5] Isro'Mukti, Y. (2017). Sistem Informasi Madrasah Aliyah Negeri Pagar Alam Berbasis Web. Indonesian Journal of Computer Science, 6(2), 192-205.

[6] Mukti, Y. (2017). Perencanaan Strategis Sistem Informasi Dan Teknologi Informasi Pada Sekolah Menengah Kejuruan Negeri 2 Pagar Alam. JURNAL ILMIAH BETRIK: Besemah Teknologi Informasi dan Komputer, 8(02), 83-92.

[7] Arif, A., \& Mukti, Y. (2017). Rancang Bangun Website Sekolah Menengah Pertama (SMP) Negeri 8 Kota Pagar Alam. JURNAL ILMIAH BETRIK: Besemah Teknologi Informasi dan Komputer, 8(03), 156-165. 
[8] Isro'Mukti, Y. (2018, October). Sistem Informasi Manajemen Aset Sekolah Tinggi Teknologi Pagaralam Berbasis Web. In Seminar Nasional Teknologi Informasi dan Komunikasi (SEMNASTIK) (Vol. 1, No. 1, pp. 632-638).

[9] Mukti, Y. (2018). Rancang Bangun Website Sekolah Dengan Metode User Centered Design (UCD). JURNAL ILMIAH BETRIK: Besemah Teknologi Informasi dan Komputer, 9(02), 84-95.

[10] Mukti, Y. (2018). Pelatihan Maintance Komputer SMAN Pagar Gunung. NGABDIMAS, $1(1), 47-51$. 